\title{
Germany - Tail Light Position in Digitisation: An Analysis of a Decentralised Tax Administration Based on the Digital European Society Index
}

\author{
DANIEL SIMON SCHAEBS \\ Pegaso International, Malta \\ info@daniel-schaebs.de
}

\begin{abstract}
This paper describes the historical reasons for a decentralised tax administration in Germany and compares different structures. With special consideration of a five-step model for the digitisation in Europe and the oECD listed challenges, an in-depth analysis of the Digital Economy and Society Index (DESI) reveals Germany's weakening position in the European context. The DESI of 2019 was adapted to cover the essential determinants of the tax administration. This adapted DESI (a-DESI) value was linked to the gross domestic product (GDP) per capita 2019 in order to include the performance of the countries. For this in-depth analysis, the new key indicator Relative Digitisation Efficiency (RDE) was developed and revealed that Germany is at the bottom of the league in digitisation, although the GDP per capita offers the country many opportunities. The decentralised tax administration could be linked to a negative impact on the progress of digitisation because of structural disadvantages.
\end{abstract}

Key words: German tax administration, decentralised tax administration, digitalisation/digitisation, Digital European Society Index (DESI)

(c) BY-SA https://doi.org/10.26493/1854-4231.15.309-323

\section{Introduction}

Digitisation is taking place in all areas of public administration. Even the tax administration has reached a point where a real paradigm shift is needed (сіат and гота 2018, 10). Many countries are already moving forward with exemplary digital solutions.

Using social networks, machine learning to interpret data/tax law, artificial intelligence, cognitive computing, blockchain technology, robotics, chat boxes to improve assessments and online portals are only some of the issues (Nazarov, Mikhaleva, and Chernousova 2019, 
145). Digitisation is the key for a tax administration to accomplish its mission in the future. But it must be understood as a process of change and not as a product that can simply be bought. This socalled digital transformation will reduce operation times and costs, and even more so improve the risk management and audit's efficiency (Microsoft and PwC 2017, 9).

This paper attempts to analyse whether a decentralised tax administration has a negative impact on the degree of digitisation. For this purpose, an analysis of Digital European Society Index (DESI) alone with reference to a five-step model for the digitisation of tax administrations in Europe is carried out. It is assumed that the DESI does not reflect the performance of the countries and therefore provides less meaningful results for the study. As part of a quantitative analysis, the adapted DESI value (a-DESI) is to be linked to the per capita income in order to be able to determine whether explicit conclusions can be drawn about the disadvantages of a decentralised structure and can be presented graphically more obviously.

\section{Historical Background for Germany}

The German tax administration has had various forms in its history. Until 1919, i.e. after the First World War, the administration was decentrally organised and the collection and administration of taxes was largely left to each federal state within its territory (Langenberg 1948, 13). From 1919 until the end of the Second World War the tax administration was centralised. All power and competences were transferred to the Weimar Republic/German Reich. During the National Socialism, this central administration played a decisive role in the plundering and expropriation of the jews (Friedensberger, Gössel, and Schönknecht 2002, 11).

Until the foundation of the Federal Republic of Germany, the Western Allies exported their respective tax administration systems to the occupation zones (Senger 2009, 38-41) and the country was divided into a mix of centralised and decentralised tax administrations. American and British administrators wanted a unified tax administration, but the French administration wanted to maintain a decentralised one, a further weakening of Germany (Senger 2009, 42).

Although the Parliamentary Council in 1949 had envisaged a central tax administration for the adoption of the German Basic Law, the Allies rejected this at the last minute (Senger 2009, 47). To date, the decentralised and shared tax administration for the Federal Republic of Germany is laid down in Article 108 of the Basic Law. The states remain the holders of state authority, but it is possible to change the 
structure of the tax administration despite the principle of eternity in Article 79 III and Article 30 of the Basic Law (Perschau 1998, 2). However, over the last 70 years Article 108 of the Basic Law has only been slightly amended.

\section{Structural Differences}

The differences in the structure of tax administrations have already been discussed extensively in the literature.

There are four typical categories for tax administration (MartinezVazquez and Timofeev 2005, 4):

1. single centralised tax authority;

2. independent tax authorities at different levels of government;

3. mixed models of tax administration;

4. fully decentralised tax authorities.

However, the distinction can be limited and simplified to two groups:

1. centralised forms - one autonomous tax administration unit with possible subdivisions (category 1);

2. decentralised forms - several autonomous tax administration units with possible subdivisions (category 2-4).

CENTRALISED TAX ADMINISTRATION

A single centralised tax authority bundles responsibility for the administration and enforcement of all taxes on a state level. Offices exist mostly at a regional and local level (Vehorn and Ahmad 1997, 112). Digitisation could especially benefit from the following advantages: uniform organisational structure, clear distribution of competencies, uniform procedures and data processing, uniform training courses and workflows (Senger 2009, 102). Senger (2009, 102), however, still assumes the disadvantage of a lower innovative ability. But Martinez-Vazquez and Timofeev $(2005,5-6)$ see in a centralised tax administration a greater specialisation of personnel and an optimised use of resources by economies of scale, especially with regard to the use of computer technology and гт-experts.

\section{DECENTRALISED TAX ADMINISTRATION}

The forms of decentralised tax administrations have in common that taxes and tax law competencies are divided. The fact that every level of government can levy taxes might also be regarded as a characteristic. In Germany for example all taxes are collected by the states for 
the central goverment and for their own. Senger $(2009,102)$ sees the advantages of greater flexibility in administration and more freedom to follow local preferences. He highlights the disadvantages resulting from a possible loss of effectiveness due to a lack of cooperation between the authorities and the different procedures, laws and forms for taxpayers (Senger 2009, 102). With regard to digitisation, there are usually many contacts that have to be brought around the table in order to implement projects. In addition, the OECD found that the overall administrative costs of tax administration are higher (OECD 2006, 107).

\section{European Context of Tax Administrations}

In general, it can be said that almost all countries in the European Union (EU 28) have a central tax administration. This may be due to the fact that the constitutions prescribe a unitary state structure and do not have any federalist aspects. For example, the ur, France, Italy and Spain of the largest economies in the $\mathrm{EU}$ have opted for centralised tax administration.

Germany with its 16 federal states plays an outsider role in the $\mathrm{EU}$. Because even among countries with a federal state structure, countries such as Austria and Belgium have opted for the central tax administration model. Other forms of decentralised tax administrations in Europe can only be found in Switzerland, Bosnia and Herzegovina and in Russia. Prominent examples outside of Europe are the usA and Canada.

\section{Digitisation of Tax Administrations}

\section{FIVE-STEP MODEL FOR THE DIGITISATION OF TAX ADMINISTRATIONS IN EUROPE}

The literature has so far dealt little with the measurement of digitisation in tax administrations. Nevertheless, one paper by Vuković (2018) also comes back to a model of Ernst \& Young Global Limited $(2017,1)$ refering to different degrees of digitisation. Based on this we can derive the following five-step model (table 1) and assign the countries in Europe.

Except Russia, countries in Europe having a decentralised tax administration (bold marked) are not playing a leading role in digitisation. Austria and Belgium, which despite their federal structure, have organised the tax administration centrally, are only on the same level as Germany. In the other European countries with central tax administrations, the classification in the categories does not show a 
TABLE 1 Five-Step Model for the Digitisation of Tax Administrations in Europe

\begin{tabular}{|c|c|c|c|c|}
\hline $\begin{array}{l}\text { (1) E-file } \\
\text { (stardardised } \\
\text { electronic } \\
\text { forms) }\end{array}$ & $\begin{array}{l}\text { (2) E-account- } \\
\text { ing (data in } \\
\text { defined elec- } \\
\text { tronic format) }\end{array}$ & $\begin{array}{l}\text { (3) E-match } \\
\text { (additional and } \\
\text { source data, } \\
\text { government } \\
\text { access + data } \\
\text { match) }\end{array}$ & $\begin{array}{l}\text { (4) E-audit } \\
\text { (cross-checks, } \\
\text { electronic au- } \\
\text { dit assess- } \\
\text { ments) }\end{array}$ & $\begin{array}{l}\text { (5) E-assess } \\
\text { (no need for } \\
\text { tax forms, au- } \\
\text { tomatic assess) }\end{array}$ \\
\hline $\begin{array}{l}\text { Albania, } \\
\text { Bosnia \& } \\
\text { Herzegov- } \\
\text { ina, Croatia, } \\
\text { Macedonia, } \\
\text { Montenegro, } \\
\text { Netherlands, } \\
\text { Serbia, Slove- } \\
\text { nia, Sweden, } \\
\text { Switzerland, } \\
\text { Ukraine }\end{array}$ & $\begin{array}{l}\text { Austria, Bel- } \\
\text { gium, Fin- } \\
\text { land, Ger- } \\
\text { many, Greece, } \\
\text { Italy, Lithua- } \\
\text { nia, Luxem- } \\
\text { bourg, Norway, } \\
\text { United King- } \\
\text { dom }\end{array}$ & $\begin{array}{l}\text { Czech Repub- } \\
\text { lic, Denmark, } \\
\text { France, Hun- } \\
\text { gary, Ireland, } \\
\text { Poland, Portu- } \\
\text { gal, Slovakia, } \\
\text { Turkey }\end{array}$ & Russia & Spain \\
\hline
\end{tabular}

NотеS Adapted from Ernst \& Young Global Limited (2017).

clear trend. In a more detailed future investigation, further factors such as the income per capita of each country would have to be used for the analysis.

However, the OECD tries to set certain standards and requirements and the countries in Europe also implement these. Design and implementation then show differences at national level (Bailey 2019). This leads us to the question of what other determinants can play a role in the digital strategy and whether the influence of the decentralised tax administration can be proven otherwise.

According to Vuković (2018), the digitisation of tax administration comprises five elements: technologies, people, managing of tax risks, financial resources, and communication. The oECD $(2017,29-$ 31) sees emerging challenges for tax administration in the following areas:

- global connectivity including cross-border processes,

- technology (paying, filing and enquiry),

- integrated and collaborated access (wider range of data, advanced analytics and risk assessment techniques, open dialog),

- effective data access (pre-filled options, interaction services with government, incorporation of tax requirements),

- better informed compliance management,

- cultural change within the workforce. 
TABLE 2 Main Indicators for Digital Public Services of DESI

\begin{tabular}{lll}
\hline 5a1 & e-Government users & $\begin{array}{l}\text { Percentage of internet users needing } \\
\text { to submit forms }\end{array}$ \\
5a2 & Pre-filled forms & Score (o to 100) \\
5a3 & Online service completion & Score (o to 100) \\
5 a4 & Digital public services for business & $\begin{array}{l}\text { Score (o to 100) - including domestic } \\
\text { and cross-border }\end{array}$ \\
5a5 & Open data & Percentage of maximum score \\
\hline
\end{tabular}

Notes Adapted from European Commission (2020).

DIGITAL ECONOMY AND SOCIETY INDEX (DESI)

By the Digital Economy and Society Index (DE SI) the European Commission summrises relevant indicators on Europe's digital performance and tracks the evolution of $\mathrm{EU}$ member States in digital competitiveness. Besides there is also an International Digital Economy and Society Index (I-DESI) for international purposes, but it is not updated annually and provides less detailed sub-categories. Both index variants have topic-related chapters, for example on analyses of broadband connectivity, digital skills, internet use, digitisation of the economy, digital public services, future technologies and cyber security. To analyse the influence of a decentralised tax administration in a European context, we have to compare Germany with the rest of the European Union by using the DESI. One chapter examines the requirements and expectations of the public sector, taking into account the supply and demand side of digital public services and open data. The values given there apply to public administration as a whole. In order to be able to draw conclusions about the tax administration, an adjustment of the index is possible, as explained below. We have to concentrate on the key performance indicators in this matter and analyse the performances of the countries. The main indicators in the chapter 'Digital Public Services' of the DESI are presented in table 2 .

Indicator $5 \mathrm{a} 1$ shows the percentage of users who submitted forms to the public administration. This quota must be constantly expanded in the course of digitisation as it is the basis for digital data instead of analog data. Also, extremely important for the promotion of digitisation is the second indicator 5a2. The administrative authorities already have a lot of their citizens' data, such as sensitive tax data. In this way it is possible to offer pre-filled declarations and documents so that citizens do not have to re-enter the data. Indicators $5^{\mathrm{a} 1}$ and $5 \mathrm{a} 2$ can be seen as a necessity for the first and second step for the before shown five-step model for the digitisation in Eu- 
rope (E-file/E-accounting). In the case of indicator $5 \mathrm{a}$, the extent to which public administration services can be concluded completely online is examined. It can be assumed that the willingness to participate in digital administration services will increase if everything can be done online. If this is only partially possible, citizens may switch completely to the analog path, as a result of which digital data for all further processes (e.g. real-time audits/e-assess) will be missing. For starting a business or conducting regular business operations, the indicator $5 \mathrm{a} 4$ stands for the availability of online and cross-border services. Since multinational tax issues are increasing, even with smaller companies, this aspect is just as important for the digitisation of tax administration. If services for companies are lacking here, the digitisation steps III-V (E-match, E-audit, E-assess) of the five-step model in particular cannot be achieved.

The composite index (DESI) in its basic composition of the Digital Public Services sector shows Germany in the bottom third of all EU 28 countries (European Commission 2020). We have to consider, that this basic composition cannot be explicitly applied to the tax administration but only to public services in general. Nevertheless, as seen above, with the categories $5 \mathrm{a} 1$ and $5 \mathrm{a} 4$ the index DESI covers the essential determinants that can be seen as a prerequisite for the digitisation of tax administration. Only the indicator $5 \mathrm{a}_{5}$ 'Open data' cannot be used for the analysis and must be removed from the DESI. The reason is that the data in the tax administration is sensitive data that is usually protected by law or data protection law. Their availability will therefore always be more limited than general data. To avoid distortions here, we have to remove category 5 a 5 and will finally form the mean of the other categories. In the following, therefore an adapted DESI (a-DESI) will be used.

\section{Adapted Digital Economy and Society Index (a-DESI) DATA COLLECTION}

For the analysis using the a-DESI the single category values of the composite DESI 2020 for the year 2019 were used (European Commission 2020). The gross domestic product (GDP) per capita figures are based on current data for the year 2019 (The World Bank 2020). All used abbreviations, components and details are listed in table 3 and table 4 .

FINDINGS USING THE A-DESI AND GDP PER CAPITA

First of all, the comparison of the GDP per capita in 2019 (constant 2010 US\$) in the respective countries with the a-DESI value leads to 
TABLE 3 Tax Administrations in the European Union

\begin{tabular}{|c|c|c|c|}
\hline Country & Abbr. & Tax administration & cen/decen \\
\hline Austria & AT & Bundesministerium für Finanzen & cen \\
\hline Belgium & $\mathrm{BE}$ & Federal Public Service Finance & cen \\
\hline Bulgaria & BG & $\begin{array}{l}\text { Natsionalna agentsia za prihodite na Republika } \\
\text { Bulgaria }\end{array}$ & cen \\
\hline Croatia & $\mathrm{HR}$ & Ministarstvo financija Republike Hrvatske & cen \\
\hline Cyprus & $\mathrm{CY}$ & Cyprus Tax Department - Tmíma Forologías & cen \\
\hline Czech Republic & $\mathrm{CR}$ & Finanční správa České republiky & cen \\
\hline Denmark & $\mathrm{DK}$ & Skattestyrelsen & cen \\
\hline Estonia & $\mathrm{EE}$ & Maksu-ja Tolliamet & cen \\
\hline Finland & FI & Vero Skatt - Tax Authority & cen \\
\hline France & FR & Direction Générale des Finances Publiques & cen \\
\hline Germany & $\mathrm{DE}$ & Finanzverwaltungen der Bundesländer & decen \\
\hline Greece & $\mathrm{EL}$ & Anexártītī Archí Dīmosíon Esódon & cen \\
\hline Hungary & $\mathrm{HU}$ & Nemzeti Adó és Vámhivatal & cen \\
\hline Ireland & IE & $\begin{array}{l}\text { Office of the Revenue Commissioners - } \\
\text { Oifig na gCoimisinéirí Ioncaim }\end{array}$ & cen \\
\hline Italy & IT & Agenzia delle Entrate & cen \\
\hline Latvia & LV & Valsts ienēmumu dienests & cen \\
\hline Lithuania & LT & $\begin{array}{l}\text { Valstybinė mokesčiu̧ inspekcija prie Lietuvos } \\
\text { Respublikos finansu̧ ministerijos }\end{array}$ & cen \\
\hline Luxembourg & LU & $\begin{array}{l}\text { Administration de l'Enregistrement, des } \\
\text { Domaines et de la TVA }\end{array}$ & cen \\
\hline Malta & MT & Office of the Commissioner for Revenue & cen \\
\hline Netherlands & $\mathrm{NL}$ & Belastingdienst & cen \\
\hline Poland & $\mathrm{PL}$ & Krajowa Administracja Skarbowa & cen \\
\hline Portugal & $\mathrm{PT}$ & Autoridade Tributária e Aduaneira & cen \\
\hline Romania & RO & Agenţia Naţională de Administrare Fiscală & cen \\
\hline Slovakia & SK & Finančná správa Slovenskej republiky & cen \\
\hline Slovenia & SI & Finančna uprava Republike Slovenije & cen \\
\hline Spain & ES & Agencia Estatal de Administración Tributaria & cen \\
\hline Sweden & $\mathrm{SE}$ & Skatteverket & cen \\
\hline United Kingdom & $\mathrm{UK}$ & Her Majesty's Revenue \& Customs & cen \\
\hline
\end{tabular}

the results shown in figure 1 . The GDP per capita is mainly used to compare the economic situation of different countries. At this point, it is intended to serve as an indicator of the prosperity in the respective country and the possibility to invest, especially in digital technology.

The dotted line indicates the $\mathrm{EU}$ average. It is the ratio of GDP per capita and a-DESI. The further away from the $\mathrm{EU}$ average, the better 
TABLE 4 Data Set

\begin{tabular}{|c|c|c|c|c|c|c|c|c|}
\hline Country & $5 \mathrm{a} 1$ & $5 \mathrm{a} 2$ & 5 a3 & $5 a_{4}$ & (1) & (2) & (3) & (4) \\
\hline $\mathrm{AT}$ & 70.0 & 81.4 & 97 & 93.1 & 85.5 & 50.655 & 153.8 & 735.8 \\
\hline $\mathrm{BE}$ & 52.9 & 70.1 & 88 & 93 & 76.0 & $47 \cdot 541$ & -253.8 & 1143.4 \\
\hline BG & 60.9 & 34.1 & 79 & 92.6 & 66.8 & 9.026 & 589.4 & 300.1 \\
\hline HR & $65 \cdot 3$ & 33.1 & 73 & $65 \cdot 3$ & 59.2 & 16.455 & 217.4 & 672.2 \\
\hline $\mathrm{CY}$ & 50.9 & 60.0 & 79 & 91.1 & 70.2 & 32.093 & -66.0 & 955.6 \\
\hline $\mathrm{Cz}$ & 50.8 & 52.5 & 82 & 79.8 & 66.3 & 23.834 & 86.4 & 803.2 \\
\hline DK & 91.2 & 68.9 & 99 & 100 & 89.7 & 65.147 & 216.9 & 672.6 \\
\hline $\mathrm{EE}$ & 93.1 & 89.6 & 98 & 100 & 95.2 & 20.742 & 789.0 & 100.6 \\
\hline FI & 94.4 & 81.9 & 96 & 92.1 & 91.1 & 49.241 & 448.9 & 440.7 \\
\hline FR & 76.2 & 39.8 & 93 & 92.6 & $75 \cdot 3$ & $44 \cdot 317$ & -205.1 & 1094.6 \\
\hline $\mathrm{DE}$ & $49 \cdot 3$ & 41.1 & 90 & 92.1 & 68.1 & 47.628 & -631.0 & 1520.5 \\
\hline EL & 39.1 & 24.5 & 84 & 63.1 & 52.8 & 24.024 & -245.6 & 1135.1 \\
\hline $\mathrm{HU}$ & 55.2 & 41.8 & 87 & $85 \cdot 3$ & $67 \cdot 3$ & 17.466 & 318.0 & 571.6 \\
\hline IE & 76.4 & 57.1 & 88 & 99 & 80.1 & 79.703 & -694.5 & 1584.1 \\
\hline IT & 32.3 & 48.3 & 92 & 94.5 & 66.9 & 35.614 & -291.0 & 1180.6 \\
\hline LV & 83.1 & 85.6 & 96 & 90.2 & 88.8 & 16.698 & 703.0 & 186.6 \\
\hline LT & 80.9 & 88.3 & 96 & 93.2 & 89.6 & 18.427 & 698.4 & 191.2 \\
\hline LU & 57.8 & 66.5 & 90 & 99 & 78.2 & 111.062 & $-15^{28.8}$ & 2418.4 \\
\hline $\mathrm{MT}$ & 56.8 & 100.0 & 100 & 93.8 & 87.7 & 28.943 & 532.1 & $357 \cdot 4$ \\
\hline $\mathrm{NL}$ & 85.9 & $77 \cdot 5$ & 90 & $84 \cdot 5$ & 84.4 & 55.690 & $19 \cdot 4$ & 870.2 \\
\hline $\mathrm{PL}$ & 54.2 & 58.0 & 87 & $75 \cdot 4$ & 68.6 & $17 \cdot 387$ & 343.6 & $545 \cdot 9$ \\
\hline $\mathrm{PT}$ & 69.8 & 81.9 & 99 & 87.5 & 84.5 & 24.590 & 507.2 & 382.4 \\
\hline RO & 82.2 & 10.4 & 70 & $53 \cdot 3$ & 54.1 & 12.131 & 332.1 & $557 \cdot 4$ \\
\hline SK & $5^{2.2}$ & 37.6 & 85 & 84.1 & 64.7 & 21.039 & 147.4 & 742.2 \\
\hline SI & 58.6 & 64.0 & 91 & 76.7 & 72.7 & 27.152 & 147.0 & 742.6 \\
\hline ES & 81.9 & 80.3 & 96 & 93.2 & 87.8 & $33 \cdot 350$ & 482.7 & 406.9 \\
\hline $\mathrm{SE}$ & 89.3 & $75 \cdot 6$ & 92 & 92.4 & $87 \cdot 3$ & 57.975 & 151.8 & 737.7 \\
\hline UK & 88.5 & 20.9 & 93 & 97.2 & 74.8 & 43.688 & -211.4 & 1100.9 \\
\hline $\mathrm{EU}$ & 67.3 & 59.4 & 90 & 87.6 & 76.0 & 37.104 & 0.0 & 889.6 \\
\hline
\end{tabular}

Notes Column geadings are as follows: (1) a-DESI 2020 (mean), (2) GDP per capita 2019 (\$), (3) RDE, (4) area.

or worse the degree of digitisation. Ireland and Luxembourg must be neglected in the consideration, because the GDP per capita stands out extremely. Possibly this can be connected with a low corporate tax policy, the large multinational corporations and the small population. However, we can see that the countries in the $\mathrm{E} \mathrm{U}$ can be divided into two groups. Countries where there is a lack of digitisation are within the area outlined in red. Among them we find Germany, Belgium, the United Kingdom, France and Italy. Countries that are at the 


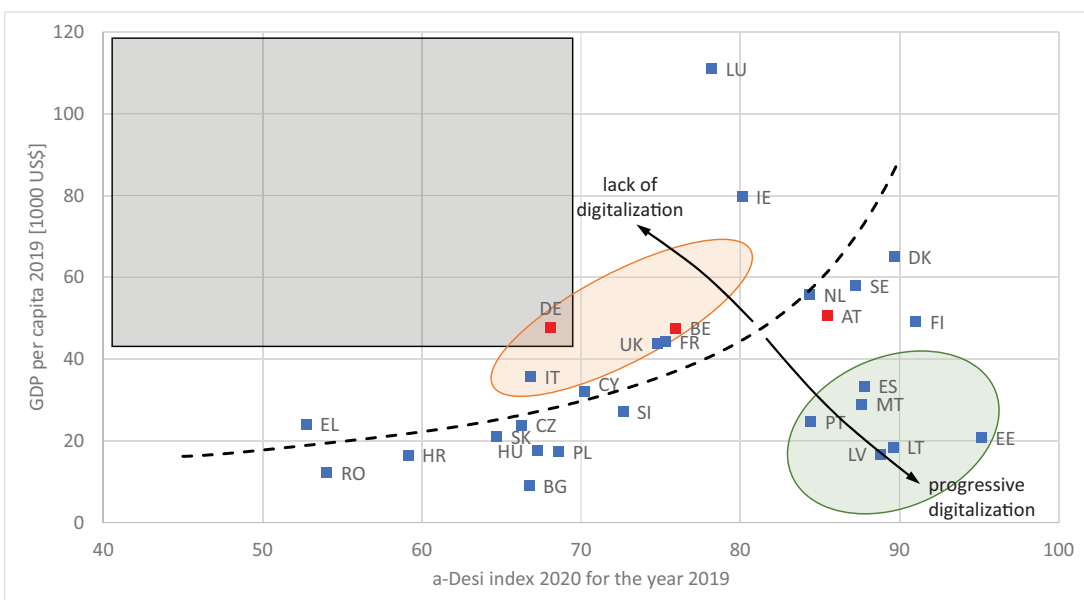

FIGURE 1 Clustering of Countries Based on the Course of the EU

forefront of digitisation are in the green-bordered area. Finland with similar GDP per capita and e.g. Spain, Estonia, Latvia and Lithuania with lower GDP per capita can be regarded as leading countries in digitisation.

The black square illustrates that there is no country in the European Union that has a comparable high per capita income and a poorer level of digitisation (a-DESI). There is no country in the EU with a comparably GDP per capita and the same low a-DESI value. Countries with the same GDP per capita have a much higher a-DESI value, such as France, Belgium, Austria or Finland. Furthermore, all countries with a similar a-DESI index have a lower GDP per capita. However, Belgium and Austria (highlighted also in red), despite their federal structure, have a better rating with their similar GDP per capita. They have a central tax administration.

In figure 2, a graphical analysis is performed. Normally, the surfaces are applied in direction o. In the case of the digitisation index, the areas are plotted in direction 100, because the closer a country is to 100 , the better it's position. The area is an indicator here, namely the product of GDP per capita and the a-DESI value. It shows how much money is available in the countries and how well digitisation is being implemented. The more prosperous a state is, the more it would have to invest in digitisation. The dotted $\mathrm{Eu}$ curve describes a balanced ratio between GDP per capita and investment in the tax digitisation progress. Each point on that curve creates an identically sized area. As an example, three areas for a low, a medium, and a high a-DESI are shown. All areas have the same size. How- 
Germany - Tail Light Position in Digitisation

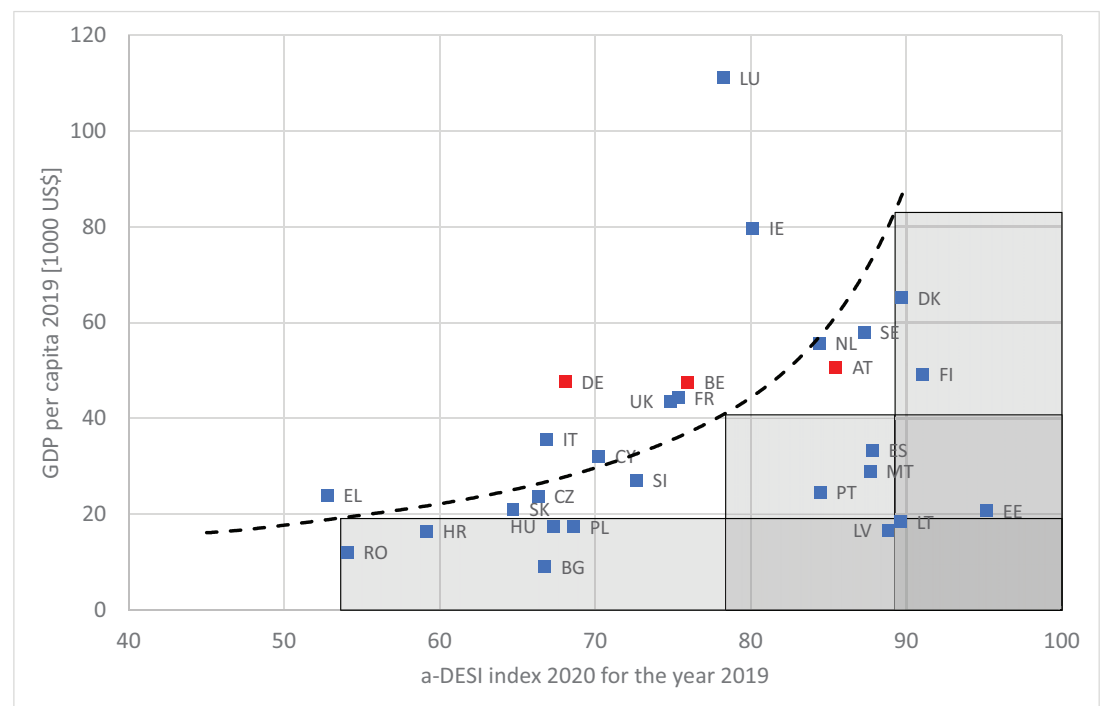

FIgURe 2 Example Areas as a Product of GDP and a-DESI

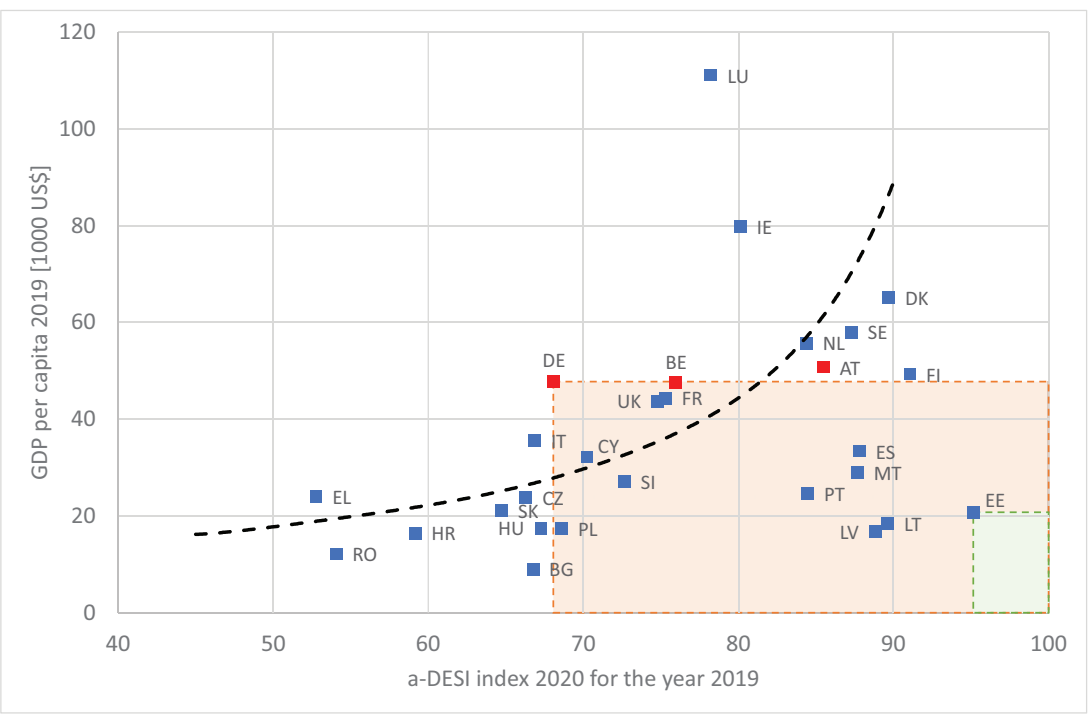

FIGURE 3 Comparison of the Areas of Germany and Estonia

ever, the smaller an area is, the better will be the Relative Digitisation Efficiency (RDE), explained and shown later. Based on this exemplary representation, the respective areas can be determined for each country. Figure 3 shows the areas for Germany (red) and Estonia (green). Germany has the largest area of the $\mathrm{EU}$, excluding 
FIGURE 4

RDE - Relative Digitization Efficiency

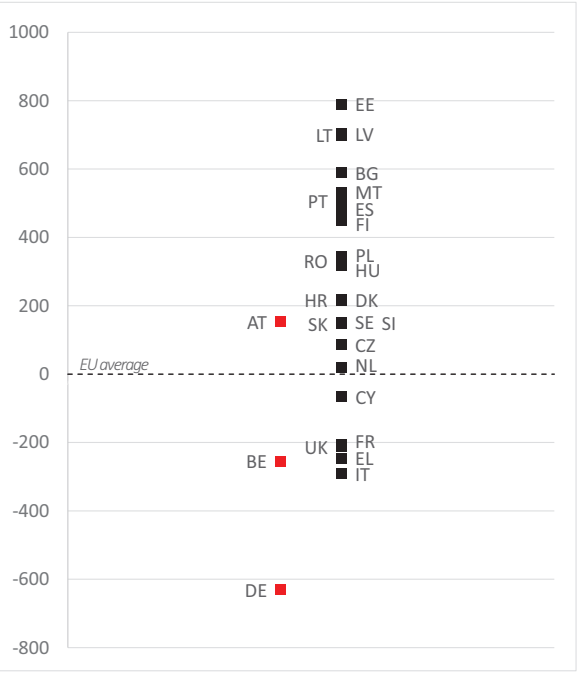

the special cases Luxembourg and Ireland. The financial resources at Germany's disposal are not invested in digitisation in a balanced ratio. In the case of Estonia, the area shown is the smallest in the $\mathrm{EU}$ and the country is investing relatively substantially in digitisation despite its rather limited financial resources.

In order to get an overview of all countries of the $\mathrm{EU}$, all calculated areas can be compared. Luxembourg and Ireland are excluded as mentioned before. The representation is done as a Relative Digitisation Efficiency ( $\mathrm{RDE}$ ) in figure 4 in relation to the $\mathrm{EU}$ average. This is set as o-point and the differences are displayed accordingly. Negative values mean that a country is worse than the $\mathrm{EU}$ average. Positive values mean that a country is better than the EU average. This form of presentation also makes it very clear that Germany has a substantial need for investment in digitisation in the context of tax administration.

\section{Conclusion}

The five-step model only led to unclear statements about the position in digitisation. However, from the DESI an adaptation to an aDESI related to tax administration was successfully implemented. By looking at the adapted DESI it could be shown that Germany has the worst position within the EU 28 states (excluding Luxembourg and Ireland). We have to assume that a country with such a high per capita income should be better represented in terms of digitisation in the tax administration. Based on the consideration according to 
the adapted DESI it becomes clear that Germany could have structural disadvantages compared to the remaining $27 \mathrm{EU}$ countries. One difference of Germany to all other Eu countries is its decentralised tax administration.

Further research must be conducted to determine whether a decentralised tax administration might have a negative impact on its degree of digitisation. As soon as a current I-DESI is available, the investigation carried out here should be extended to see if the trend can be confirmed by other countries with decentralised tax administrations.

A position paper of the Federal Ministry of Finance in 2004 had already determined that the 16 independent tax administrations lead to considerable disadvantages for Germany (Bundesministerium der Finanzen 2004, 1-3). Some of the disadvantages assumed there can have an adverse effect on digital transformation. In their counterassessment, the finance ministers of the federal states claim that it is not federalism in the tax administration, but German tax law that is causing the disadvantages (Finanzministerkonferenz 2004, 4). This should be part of a further research.

\section{Discussion}

Data on the digitization of the tax administration of the individual federal states of Germany are not available or only sparse. This paper attempts to address this issue by using an adapted DESI, a more meaningful representation can be made, as assumed at the beginning. However, the informative value of the DESI for the tax administration is limited because the index only analyses the public administration in general and thus does not take into account any special features. Nevertheless, it could be shown that Germany performs worst in the case of the developed a-DESI. However, the extent to which this is exclusively due to the decentralised structure remains questionable. The organization of the tax administration in Germany is very complex, so that certainly no monocausality can be assumed and consequently limits the investigation. There are multiple factors that can influence the DESI value. But decentralisation seems to be a crucial contributing factor.

\section{References}

Bailey, H. 2019. 'A New Digital Era for Revenue Authorities.' https://www .ey.com/en_gl/tax/how-tax-administration-is-going-digital.

Bundesministerium der Finanzen. 2004. 'Effizienz und Effektivität in der Steuerverwaltung - Positionspapier des Bundesministeriums 